\title{
Minishelterins separate telomere length regulation and end protection in fission yeast
}

\author{
Lili Pan, ${ }^{1,2}$ Katie Hildebrand, ${ }^{1}$ Cian Stutz, ${ }^{3}$ Nicolas Thomä, ${ }^{3}$ and Peter Baumann ${ }^{1,2,4}$ \\ ${ }^{1}$ Stowers Institute for Medical Research, Kansas City, Missouri 64110, USA; ${ }^{2}$ Department of Molecular and Integrative Physiology, \\ University of Kansas Medical Center, Kansas City, Kansas 66160, USA; ${ }^{3}$ Friedrich Miescher Institute for Biomedical Research, \\ 4058 Basel, Switzerland; ${ }^{4}$ Howard Hughes Medical Institute, Kansas City, Missouri 64110, USA
}

The conserved shelterin complex is critical for chromosome capping and maintaining telomere length homeostasis. In fission yeast, shelterin is comprised of five proteins. Taz1, Rap1, and Poz1 function as negative regulators of telomere elongation, whereas Pot1 and Tpz1 are critical for end capping and telomerase recruitment. How the five proteins work together to safeguard chromosome ends and promote telomere length homeostasis is a matter of great interest. Using a combination of deletions, fusions, and tethers, we define key elements of shelterin important for telomere length regulation. Surprisingly, deletion of the entire Rap1 and Poz1 proteins does not impair telomere length regulation as long as a static bridge is provided between Taz1 and Tpz1. Cells harboring minishelterin display wild-type telomere length and intact subtelomeric silencing. However, protection against end fusions in G1 is compromised in the absence of Rap1. Our data reveal a remarkable plasticity in shelterin architecture and separate functions in length regulation and end protection.

[Keywords: telomere; shelterin; fission yeast; telomerase; telomere length regulation; end protection]

Supplemental material is available for this article.

Received February 25, 2015; revised version accepted May 12, 2015.

Telomeres, the nucleoprotein structures at the ends of linear chromosomes, are essential for maintaining genome integrity. In most eukaryotes, telomeric DNA consists of tandem repeat sequences terminating in a singlestranded overhang at each chromosome end. Telomeres are extended by the reverse transcriptase telomerase that uses part of an RNA subunit to template telomere repeat synthesis (Pfeiffer and Lingner 2013). This widely conserved mechanism of telomere elongation solves the end replication problem caused by the inability of conventional DNA polymerases to fully replicate linear chromosomes. Within a species, organism, or cell type, telomere length is maintained within a specific size range. Telomere length homeostasis is at least in part mediated via a cis-inhibitory feedback mechanism that limits further elongation of long telomeres and favors lengthening of the shortest telomeres (Marcand et al. 1999). The end replication problem, nucleolytic processing, and stochastic rapid deletion events contribute to telomere shortening, while replenishment of telomeric DNA by telomerase is a highly regulated process that requires mechanisms to sense the lengths of individual telomeres and regulate recruitment to and/or processivity of the enzyme at a specif-

Corresponding author: peb@stowers.org

Article is online at http://www.genesdev.org/cgi/doi/10.1101/gad.261123. 115. ic chromosome end. Telomere-binding proteins play a key role in transducing information about telomere length and switching telomeres between telomerase-accessible and -inaccessible conformations (Teixeira et al. 2004).

In fission yeast, interactions among five proteins form a putative bridge between the single- and double-stranded parts of the telomere (see the schematic in Fig. 1A). The Tazl protein binds double-stranded telomeric repeats and is structurally and functionally similar to human TRF1 and TRF2 (Broccoli et al. 1997; Cooper et al. 1997). Tazl recruits Rap1 to telomeres (Chikashige and Hiraoka 2001; Kanoh and Ishikawa 2001). The single-stranded overhang is bound by Pot1 in complex with Tpzl (Baumann and Cech 2001; Miyoshi et al. 2008); these are orthologs of human POT1 and TPP1 (Baumann and Cech 2001; Houghtaling et al. 2004; Liu et al. 2004; Ye et al. 2004). Pozl interacts with both Rapl and Tpzl, thereby bridging the proteins bound to the single- and double-stranded parts of the chromosome end (Miyoshi et al. 2008). Deletion of taz1, rap1, or poz1 leads to dramatic telomere elongation, indicative of these proteins

(C) 2015 Pan et al. This article is distributed exclusively by Cold Spring Harbor Laboratory Press for the first six months after the full-issue publication date (see http://genesdev.cshlp.org/site/misc/terms.xhtml). After six months, it is available under a Creative Commons License (Attribution-NonCommercial 4.0 International), as described at http:// creativecommons.org/licenses/by-nc/4.0/. 
A
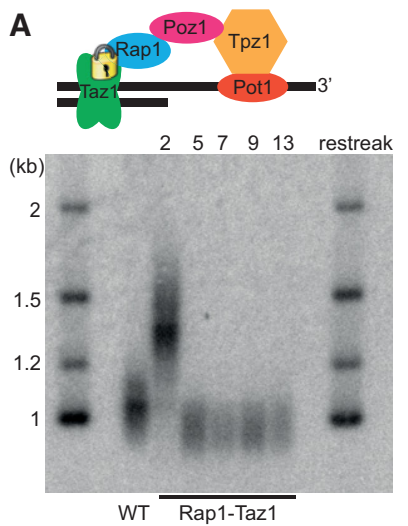

WT Rap1-Taz1
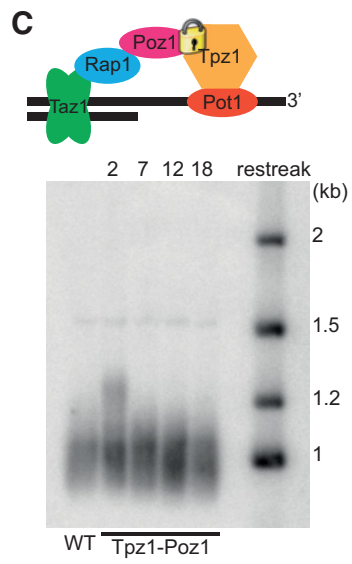

B

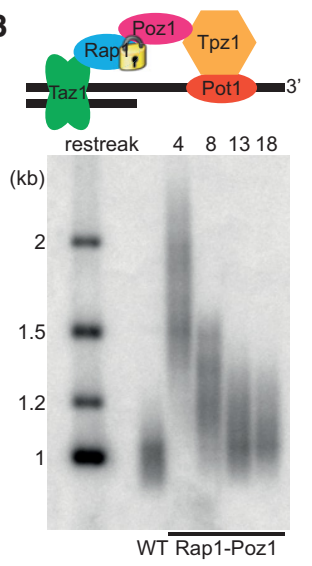

D

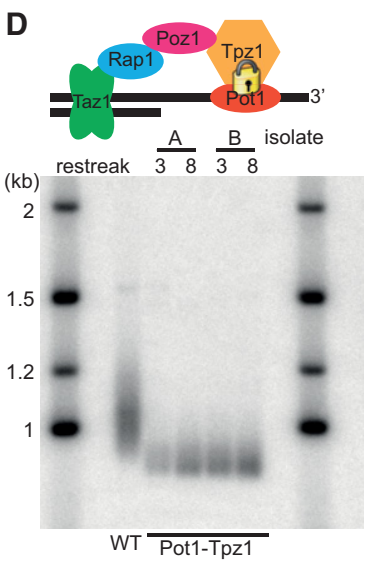

Figure 1. Locking protein interactions with covalent linkers. In each case, the construct encoding a fusion between two telomeric proteins was integrated at the genomic locus of the $\mathrm{N}$-terminal partner, driven by its native promoter, and the genes encoding the individual proteins were deleted. The linker sequence corresponds to the V5 epitope tag. Following the indicated number of sequential restreaks, telomere length was assessed by Southern blotting of EcoRI-digested genomic DNA probed with a telomerespecific probe. Each restreak corresponds to 20-25 generations.

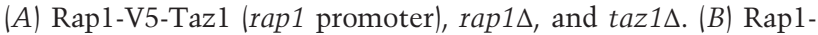
V5-Poz1 (rap1 promoter), rap1 1 , and poz1 1 . (C) Tpz1-V5-Poz1 (tpz1 promoter), tpz1 1 , and poz1 $\Delta$. (D) Pot1-V5-Tpz1 (pot1 promoter), pot $1 \Delta$, and $t p z 1 \Delta$.

functioning as negative regulators of telomere length (Cooper et al. 1997; Chikashige and Hiraoka 2001; Kanoh and Ishikawa 2001). Deletion of taz1 or rap1 also causes chromosome end fusions in G1-arrested cells, supporting a role for Taz1/Rap1 in protecting chromosome ends from nonhomologous end-joining (NHEJ) (Ferreira and Cooper 2001; Miller et al. 2005). The Pot1/Tpzl complex is critically important for telomere maintenance, as deletions of either causes rapid telomere loss (Baumann and Cech 2001; Miyoshi et al. 2008). Together with Ccq1, Pot1/ Tpzl also plays a key role in the recruitment of telomerase (Jun et al. 2013; Harland et al. 2014).

Disruption of individual protein-protein interactions between telomeric proteins leads to telomere elongation (Chen et al. 2011; Fujita et al. 2012; Jun et al. 2013), sug-

gesting that dynamic interactions may be important for telomere length homeostasis. Here we examined the contributions of each core component of the telomeric complex to the maintenance of telomere length homeostasis. We found that, with respect to telomere length regulation, Rap1 and Poz1 serve solely as interaction modules that can be replaced by a short peptide linker. In this way, we created simplified telomeric complexes (minishelterins) that maintain wild-type telomere length. These cells show no growth defect and retain transcriptional silencing of a telomere-proximal reporter. However, minishelterin complexes fail to protect against chromosome end fusions in G1-arrested cells, thereby separating functions of telomeric proteins in length regulation and end protection.

\section{Results}

The observation that a series of protein-protein interactions form a bridge between the double- and single-stranded parts of a telomere raised the possibility that this structure underlies a "closed" or inaccessible conformation of the telomere. An "open" and thereby telomeraseaccessible conformation may require regulated disassembly of the complex or disruption of a protein-protein interaction that breaks the bridge. To test whether any of the interactions within the complex are critical for telomere length regulation, we replaced each individual interaction with a covalent linker that permanently joins neighboring proteins. When endogenous rap1 was replaced with a rap1taz1 fusion in the context of a taz1 deletion, the long telomeres caused by the taz 1 deletion gradually shortened and stabilized close to wild-type length (Fig. 1A). Telomeres in these cells were indeed maintained by telomerase, as deletion of the catalytic subunit of telomerase trt1 resulted in telomere loss (Supplemental Fig. S1A). Similarly, fusions of Rap1 and Pozl as well as Pozl and Tpzl maintained stable telomeres similar to wild type in length (Fig. 1B,C). Since deletion of pot 1 or tpz 1 causes complete telomere loss within one cell cycle, a pot1-tpz1 fusion was first integrated at the pot1 locus followed by deletion of the tpz1 gene. The resulting strain maintained stable yet shorter than wild type telomeres (Fig. 1D). Despite the reduction in telomere length, capping remained largely intact, as the doubling time of the Pot1-Tpzl fusion strain was indistinguishable from wild type (123.9 $\mathrm{min} \pm 1.1$ min for fusion, and $125.8 \mathrm{~min} \pm 1.3 \mathrm{~min}$ for wild type), Chk1 phosphorylation was undetectable, and few cells were elongated (Supplemental Fig. S2). The short telomere phenotype may indicate that a dynamic Pot1-Tpzl interface is important in regulating telomere length. Alternatively, the new telomere length set point may simply reflect a functional impairment caused by the fusion. In any event, a dynamic Pot1-Tpzl interface is not critical for stable telomere maintenance, as telomere length remained unchanged for well over 100 generations at the shorter set point. Deletion of trt1 in each of the strains confirmed that none of the fusions caused a switch from telomerase-mediated to recombinational telomere 
maintenance (Supplemental Fig. S1). The absence of progressive telomere shortening in telomerase-positive strains harboring any of the fusions indicates that telomerase access does not depend on the dynamic opening of one specific interaction. The results leave open the possibility of redundant dynamic interfaces or interactions in trans.

\section{Requirements for Taz1 in telomere length maintenance}

Several domains have been identified in Tazl based on functional analyses and homology with mammalian TRF1/2 (Fig. 2A). A TRF homology (TRFH) domain is present near the $\mathrm{N}$ terminus. Related sequences in mammalian TRF1 and TRF2 proteins mediate homodimerization as well as interaction with other telomeric proteins (Fairall et al. 2001). A region around amino acids 365-396 is required for the recruitment of Rap1 to telomeres /Chen et al. 2011), and telomere binding is mediated by the Myb domain located near the C terminus (Cooper et al. 1997). DNA binding by Taz1 requires homodimerization (Spink et al. 2000), but, unlike in mammalian TRF proteins, this interaction is not mediated by the TRFH domains (Chen et al. 2011). Instead, a C-terminal fragment of Tazl (Taz1C) starting at amino acid 408 can dimerize with full-length Taz1 (Fig. 2B), indicating that amino acids between 408 and 552 are responsible for this interaction.

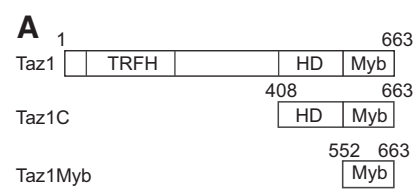

B

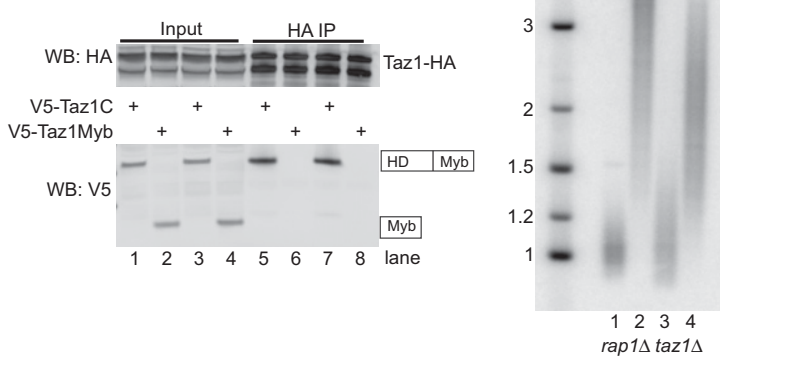

Figure 2. DNA binding and dimerization domains of Tazl are sufficient for near wild-type telomere length maintenance. $(A)$ Schematic of Tazl and Tazl truncation mutants. Numbers indicate amino acid positions. (HD) Homodimerization domain; $(\mathrm{Myb})$ myb domain. (B) Coimmunoprecipitation of V5-tagged Taz1Myb and Taz1C with HA-tagged Tazl. (Top panel) Western blot for input $(10 \%)$ and immunoprecipitate probed with anti-HA for full-length Tazl. The lower band is the result of translational initiation at an internal ATG in Tazl (J Cooper, pers. comm.). (Bottom panel) Western blot probed with anti-V5 to detect Taz1C (lanes 1,3,5,7) and Taz1Myb (lanes 2,4,6,8). Samples shown in lanes $3,4,7$, and 8 were treated with benzonase prior to immunoprecipitation to assess whether protein interactions are mediated by nucleic acid. (C) Telomere length analysis for strains deleted for rap 1 and taz 1 and harboring the indicated constructs under control of the nmt81 promoter. Genes deleted in lanes not labeled "WT" are shown below the blot.
Treatment with benzonase confirmed that the interaction is not dependent on nucleic acid (Fig. 2B, lane 7). To test whether Taz1 binding to telomeric DNA is sufficient for length regulation, we fused the Taz1C fragment to the $\mathrm{C}$ terminus of Rap1. This Rap1-Taz1C fusion protein was sufficient to rescue the dramatic telomere elongation phenotype observed following deletion of taz1 and rap1 (Fig. 2C, lane 3; Supplemental Fig. S3A). Fusing just the Taz1Myb domain to Rap1 partially rescued the long telomere phenotype (Fig. 2C, lane 4), presumably due to Rap1 mediating dimerization through a previously reported weak self-association (Kanoh and Ishikawa 2001). These results show that the N-terminal 407 amino acids of Taz1, including the entire TRFH domain, are dispensable for telomere length regulation as long as Tazl is physically connected to Rap1. Expressing Taz1C or Taz1Myb alone did not rescue telomere length (Supplemental Fig. S3B). In summary, these results indicate that telomere length regulation requires binding of Tazl to telomeric repeats as well as a physical connection with Rap1.

\section{Replacement of Rap1 and Poz1 with synthetic linkers}

The N-terminal part of Rap1 contains a BRCT domain, a Myb domain, and a Myb-like (Myb-L) domain, whose functions have yet to be characterized despite their conservation among species (Chikashige and Hiraoka 2001; Kanoh and Ishikawa 2001). Rap1 interacts via its C-terminal RCT domain with Tazl (Chen et al. 2011). In addition, we mapped the Pozl interaction (PI) domain to amino acids 440-490 (Supplemental Fig. S4A), which is similar to amino acids 457-512, recently reported (Fujita et al. 2012). We examined the role of each domain in telomere length regulation by deleting them individually (Supplemental Fig. S4B). Mutants lacking the BRCT, Myb, or Myb-L domain maintained wild-type telomere length, whereas Rap $1 \Delta \mathrm{PI}$ and $\mathrm{Rap} 1 \Delta \mathrm{RCT}$ cells had $>10$-fold longer telomeres than wild type (Supplemental Fig. S4C). To test whether any of the three N-terminal domains function redundantly and whether sequences between the domains play a role in telomere length regulation, larger truncations were made and introduced into cells lacking endogenous Rap1 (Fig. 3A). We found that the N-terminal 63\% of the protein (amino acids 1-439) is dispensable for wildtype telomere length maintenance (Fig. 3A). The remaining C-terminal region of Rapl contains the Pozl and Tazl interaction domains.

To test whether providing a molecular bridge between Tazl and Pozl was the sole function of Rap1 in telomere length maintenance, we fused the PI domain of Rap1 (amino acids 440-490) via a 14-amino-acid synthetic linker to the $\mathrm{C}$ terminus of Taz1. Cells containing this fusion maintained wild-type telomeres in the absence of endogenous Tazl and Rap1 (Fig. 3B, lanes 1-4). Similarly, fusing the Taz1-interacting domain of Rap1 (RCT domain; amino acids 639-693) to the C terminus of Pozl caused telomeres to shorten to wild-type length in a rap 1 and poz1 deletion background (Fig. 3B, lanes 5-9). Both strains lost telomeres following trt1 deletion, confirming that telomeres were maintained by telomerase (Supplemental Fig. S4D, 
A
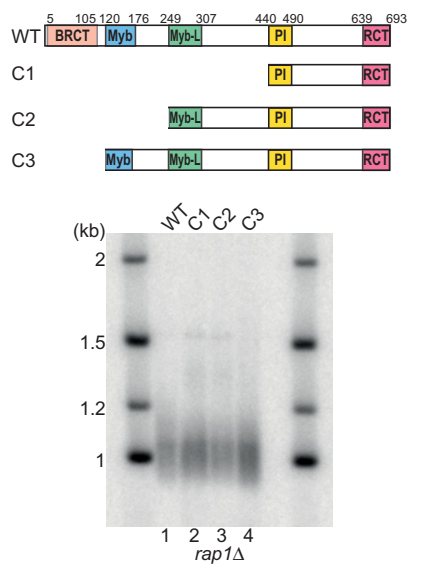

B

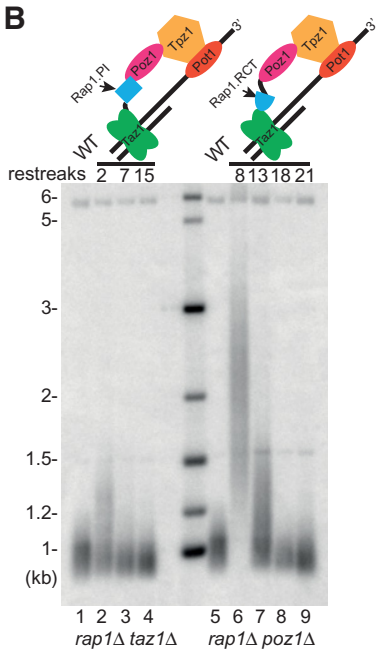

Figure 3. Rap1 functions as an interaction module in telomere length maintenance. (A) Telomere length analysis for the truncation mutants shown in the schematic. Strains were constructed by introducing Rap1 fragments under the control of the nmt81 promoter into a rap1 $1 \Delta$ strain and were subjected to 14 sequential restreaks prior to telomere length analysis. Genes deleted in lanes not labeled "WT" are shown below the blot. (B) Replacement of RCT and PI domains of Rap1 with covalent linkers to Tazl and Pozl, respectively. The PI domain (amino acids 440-490) of Rap1 was placed downstream from Taz1 and a V5 epitope tag under the control of the taz1 promoter in a taz1 $\operatorname{rap} 1 \Delta$ strain. The RCT domain (amino acids 639-693) of Rap1 was expressed inframe with Pozl and a V5 epitope tag under the control of the poz1 promoter in a poz1 1 rap $1 \Delta$ strain. The fusion constructs were integrated into the genome at the sites of the taz1 and poz1 genes, respectively. Genes deleted in lanes not labeled "WT" are shown below the blot.

E). These results strongly suggest that the role of Rap1 in telomere length regulation is to provide a molecular bridge between Tazl and Pozl. We therefore predicted that the entire Rap1 protein could be replaced with a synthetic linker. However, when we expressed Taz1-Pozl in taz1 1 rap $1 \Delta$ poz $1 \Delta$ cells, telomeres remained long (Fig. 4A, lanes 2-4). In order to test whether this was a consequence of the orientation of the fusion, we switched Pozl to being the $\mathrm{N}$-terminal partner. Again, the fusion protein failed to rescue (Fig. 4A, lanes 5,6). This result may indicate that the PI and RCT domains have redundant functions in inhibiting uncontrolled telomere elongation. Alternatively, the synthetic fusion of the two proteins may affect folding or expression level, or the synthetic linker between Taz1 and Pozl may be too short to partake in the proposed higher-order structure that forms the telomerase-inaccessible state. Interestingly, we found that the Pozl-Tazl fusion maintained wild-type telomere length in rap1 $1 \Delta$ and poz1 $\Delta$ cells as long as endogenous $t a z 1^{+}$was present (Fig. 4C). This repudiates the necessity for any part of Rap1 and instead indicates that the defect relates to Tazl function or protein level.

As Pozl lacks an obvious domain structure, we replaced the entire protein with a 14-amino-acid peptide linking

Tpzl and Rap1. This fusion protein expressed from the Tpzl promoter rescued wild-type telomere length in the absence of endogenous Poz1 (Fig. 4B, lanes 2-5), indicating that Pozl solely functions in length regulation by acting as a tether between Rap1 and Tpzl. Based on these results, a new fusion was constructed that connects Tpzl to the
A
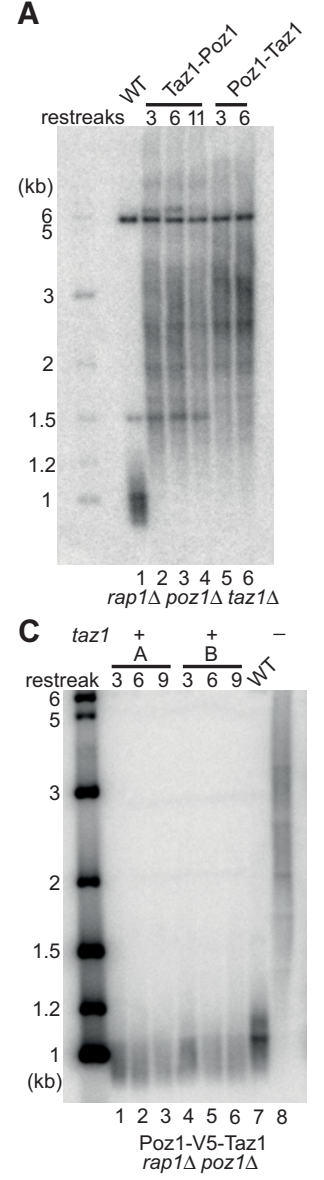

B

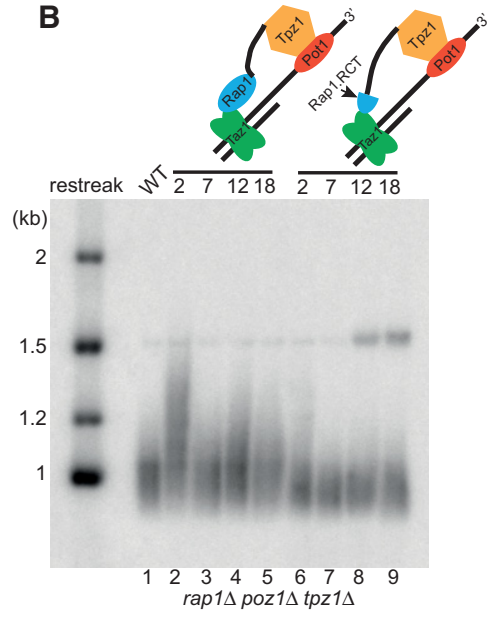

D

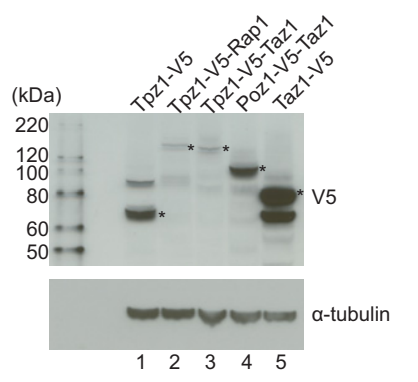

Figure 4. Effect of replacing Rap1 and Poz1 with covalent linkers. (A) Taz1-Poz1 and Poz1-Taz1 fusions fail to rescue telomere elongation associated with deletion of rap1. The fusion constructs were integrated at the genomic locus and are driven by the promoter of the $\mathrm{N}$-terminal fusion partner. The endogenous copies of poz1 and taz1 were deleted. Genes deleted in lanes not labeled "WT" are shown below the blot. (B) Telomere elongation associated with deletion of poz1 is rescued by fusing Tpz 1 via a V5 epitope linker to Rap1 (lanes 2-5) or the RCT of Rap1 (lanes 6-9). The integration strategy was as described in $A$. Genes deleted in lanes not labeled "WT" are shown below the blot. $(C)$ Telomere elongation associated with replacing taz1, rap1, and poz1 with a poz1-taz1 fusion is rescued in the presence of endogenous taz1. Telomere length analysis for two independent isolates is shown. Genes deleted in lanes not labeled "WT" are shown below the blot. (D) Analysis of protein levels for Tpz1, Taz1, and fusion constructs by Western blot. All proteins are V5 epitopetagged at the endogenous locus for Tpzl and Tazl and at the locus of the N-terminal partner for fusion constructs. An antibody against $\alpha$-tubulin was used as a loading control. The asterisks indicate bands of the correct size in each lane. The identity of the $90-\mathrm{kDa}$ band in lane 1 is unknown. 
RCT domain of Rap1 (Tpz1-Rap1_RCT). Cells harboring this protein maintained wild-type telomere length in the absence of both Rap1 and Poz1 (Fig. 4B, lanes 6-9). As in previous experiments, telomere maintenance was fully dependent on telomerase (Supplemental Fig. S5A,B).

Tpz1-Taz1 can function in length regulation as a minishelterin

As replacement of either Rap1 or Poz1 by a synthetic linker did not compromise telomere length regulation, it was tempting to test whether a fusion between Tpz1 and Taz1 would entirely eliminate a need for Rap 1 and Poz1 in telomere length control. We integrated tpz1-taz1 under the control of the tpz1 promoter at the tpz1 locus in the background of a triple taz1 rap1 poz1 deletion. The expression level of the fusion protein was found to be similar to Tpz1-Rap1 but much lower than the endogenous level of Tpz1 or Tazl (Fig. 4D, cf. lanes 3 and 1,5). Note that Pozl-Tazl was also expressed at a lower level compared with Taz1 (Fig. 4D, cf. lanes 4 and 5). Similar to what we observed in Pozl-Taz1 cells, telomeres were still elongated in the presence of the Tpz1-Tazl fusion protein (Fig. $5 \mathrm{~A})$, and the presence of endogenous Taz1 protein rescued telomere length (Fig. 5B). These results support the notion that Tazl levels play a key role in length regulation. They further suggest that the number of Tpzl molecules required for length regulation is much lower than the number present in wild-type cells. It is worth noting in this context that the protein level of Tpz1-Rap1 was also much lower than endogenous Tpz1 (Fig. 4D, cf. lanes 2 and 1).

To determine whether the total amount of Tazl is important or whether free Tazl itself is required, we increased the expression of the tpz1-taz1 fusion by integrating one or more copies under the control of the repressed nmt1 promoter (Supplemental Fig. S6A). One of the resulting strains expressed the fusion protein at a level similar to that of endogenous Tazl, and another strain expressed about twice the amount (Fig. 5C). Expressing Tpzl-Tazl at a level similar to that of endogenous Tazl was sufficient to largely rescue telomere length in a taz1 $\Delta$ background (Fig. 5D, lanes 7-11). A twofold higher level of Tpz1-Tazl resulted in even fewer elongated telomeres, and the new length equilibrium was reached faster compared with the strain with the lower amount of Tpz1-Taz1 fusion (Fig. 5D, lanes 2-6). Therefore, while the total Tazl protein level is important for telomere length control, the protein can be present in either the fusion or a combination of the fusion and free Tazl. Each strain maintained telomeres in a telomerasedependent manner (Supplemental Fig. S6B-D). The results further confirm that the entire Rap1 and Poz1 proteins function as an interaction module with respect to length homeostasis. Perhaps most surprisingly, the physical distance between Tpzl and Tazl and thus between the double- and the single-stranded parts of the telomere is not critical, as a 14-amino-acid linker can substitute for two proteins with a combined molecular weight of $109 \mathrm{kDa}$. In summary, we generated two strains in which
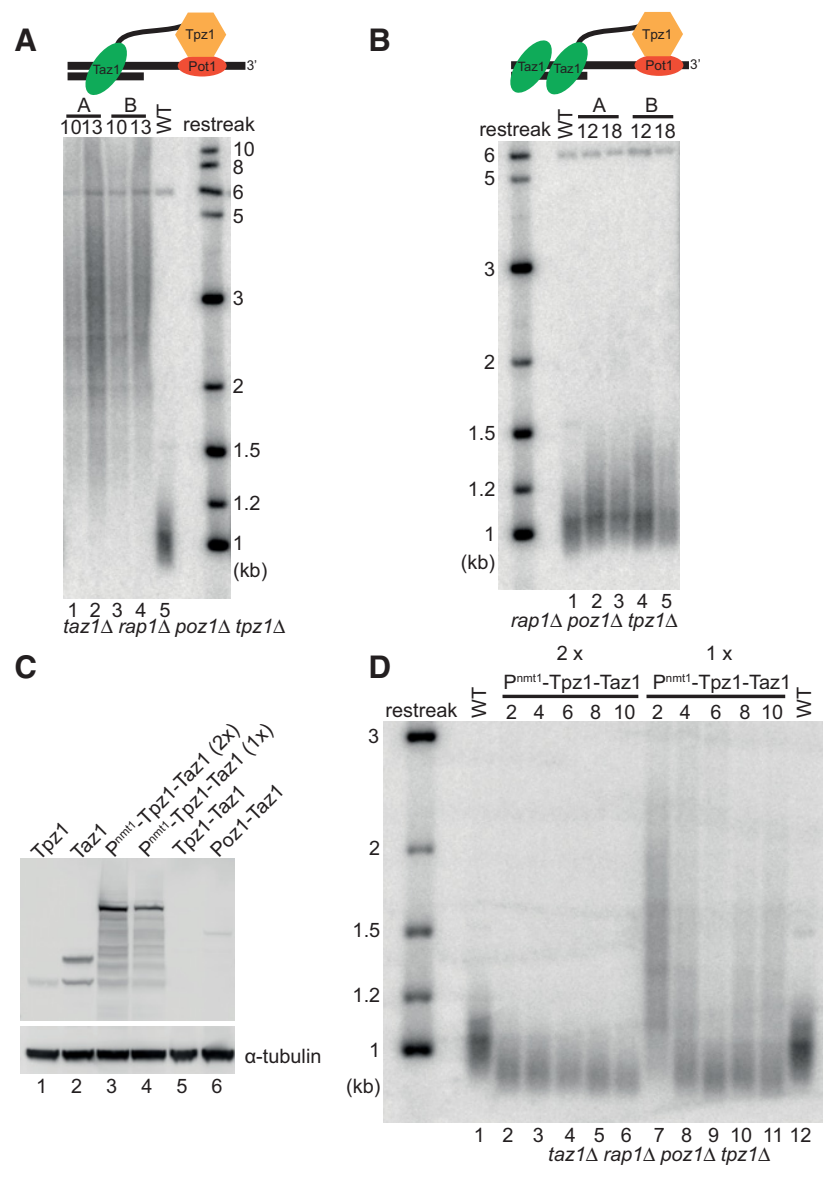

Figure 5. Telomere length maintenance is sensitive to the level of Taz1. (A) Tpz1-Tazl expression is insufficient to prevent telomere elongation in the absence of endogenous Taz1. Genes deleted in lanes not labeled "WT" are shown below the blot. (B) Tpz1Tazl maintains normal telomeres in the presence of endogenous Taz1 but in the absence of Tpz1, Poz1, and Rap1. Genes deleted in lanes not labeled "WT" are shown below the blot. (C) Determination of protein levels by Western blot analysis. Tpz1-Taz1 was integrated at the aur 1 locus under the control of the nmt1 promoter. (D) Telomere length analysis of strains expressing Tpzl-Tazl fusions in the absence of endogenous Taz1, Rap1, Poz1, and Tpzl. Genes deleted in lanes not labeled "WT" are shown below the blot.

simplified telomeric complexes maintain wild-type telomere length.

\section{Minishelterin maintains telomere position effect (TPE) and protects against telomere entanglements}

In addition to dramatic telomere lengthening, deletion of either taz1 or rap1 causes several other telomeric phenotypes, including increase in recombination, loss of TPE, and, in the case of $\operatorname{taz} 1 \Delta$, telomere entanglements when cells are grown at low temperature (Ferreira and Cooper 2001; Kanoh and Ishikawa 2001; Miller and Cooper 2003; Miller et al. 2005; Fujita et al. 2012). The minishelterin provided an opportunity to examine whether these 
A

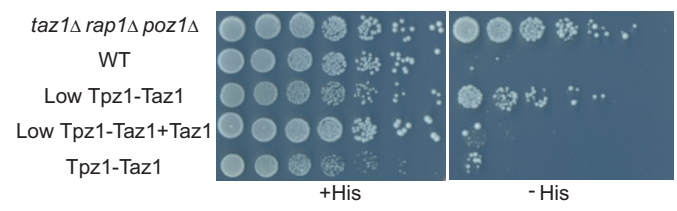

B

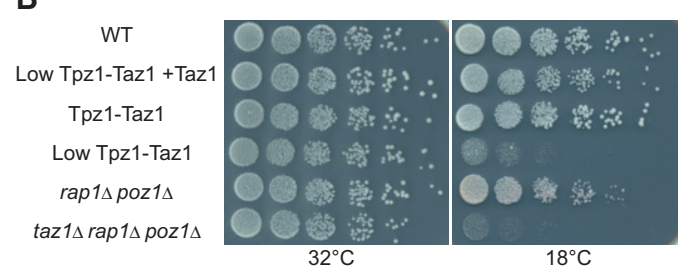

Figure 6. Minishelterin supports TPE and cold resistance. (A) TPE of minishelterin cells. The telomere-proximal his $3^{+}$marker is transcriptionally repressed in wild-type cells due to TPE. Spotting assays were done with 1:5 serial dilutions starting with $4 \times$ $10^{4}$ cells per spot and plated on PMG $+\mathrm{ALUH}(+\mathrm{His})$ and PMG + ALU (-His). (B) Cell growth in the cold. Serial dilutions (1:5) of mid-log-phase cells starting with $8 \times 10^{3}$ cells per spot were plated on YES and incubated at $32^{\circ} \mathrm{C}$ and $18^{\circ} \mathrm{C}$, respectively.

phenotypes are separable from defects in telomere length regulation. When the his $3^{+}$gene is moved from its normal location on chromosome II to a site adjacent to a telomere, subtelomeric silencing causes repression, and otherwise wild-type cells fail to grow in histidine-free medium (Cooper et al. 1997; Nimmo et al. 1998). Previous studies have shown that subtelomeric silencing is alleviated in cells deleted for taz1, rap1, or poz1 (Cooper et al. 1997; Kanoh and Ishikawa 2001; Fujita et al. 2012). As expected, robust growth was observed in the taz1 $1 \Delta$ rap $1 \Delta$ poz1 $1 \Delta$ triple deletion (Fig. 6A). Introduction of either minishelterin into these cells resulted in almost complete rescue of subtelomeric silencing, as indicated by growth inhibition on medium lacking histidine. These results suggest that the presence of Taz1 in combination with a physical tether to $T p z 1$ is sufficient to maintain repressive chromatin near telomeres. In contrast, and correlating with the elongated telomere phenotype, cells harboring low levels of the Tpz1-Tazl fusion in the absence of free Tazl protein did not maintain TPE.

Cells lacking taz1 have a severe growth defect at $20^{\circ} \mathrm{C}$, as telomere entanglements fail to be resolved during mitosis (Miller and Cooper 2003; Miller et al. 2005). Deletion of Rap1 exacerbates the cold sensitivity of taz1 $1 \Delta$ cells but has no effect on growth by itself (Miller et al. 2005). Consistent with these observations, we found that the taz1 $\operatorname{rap} 1 \Delta$ poz1 $\Delta$ triple deletion fails to grow at $18^{\circ} \mathrm{C}$, whereas a rap $1 \Delta$ poz $1 \Delta$ strain grows well (Fig. 6B). While cells expressing low levels of Tpz1-Taz1 were

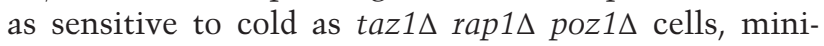
shelterin fully rescued the growth defect. These results support that the level of Tazl protein is critical for growth at cold temperatures, whereas Rap1 and Poz1 are dispensable.
A direct role for Rap1 in protecting against chromosome end fusions in G1

NHEJ-mediated chromosome fusions occur when cells lacking taz1 or rap1 are arrested in G1 (Ferreira and Cooper 2001; Miller et al. 2005). As either deletion causes massive telomere elongation, it had remained unclear whether telomere elongation is linked to the loss of end protection in G1 or whether the two events are separable. We thus examined G1-arrested minishelterin cells for the presence of chromosome end fusions. Despite wild-type telomere length, neither minishelterin protected chromosome ends from fusions (Fig. 7A). In addition to Tpz1 and some or all of Tazl being present as chimeric fusion, the minishelterin strains lack Rap1 and Poz1. To investigate whether the absence of either protein was responsible for the end protection phenotype, we reintroduced either rap1, poz1, or both together. Strikingly, chromosome end fusions were absent in cells expressing Rap1 alone or Rap1 and Poz1 (Fig. 7B, lanes 2,4). In contrast, expression of Pozl alone was insufficient to prevent end fusions (Fig. 7B, lane 3). These results provide two fundamental insights: First, Rap1, but not Poz1, contributes to preventing chromosome end fusions in G1. Second, Rap1 is not functioning simply by maintaining wild-type telomere

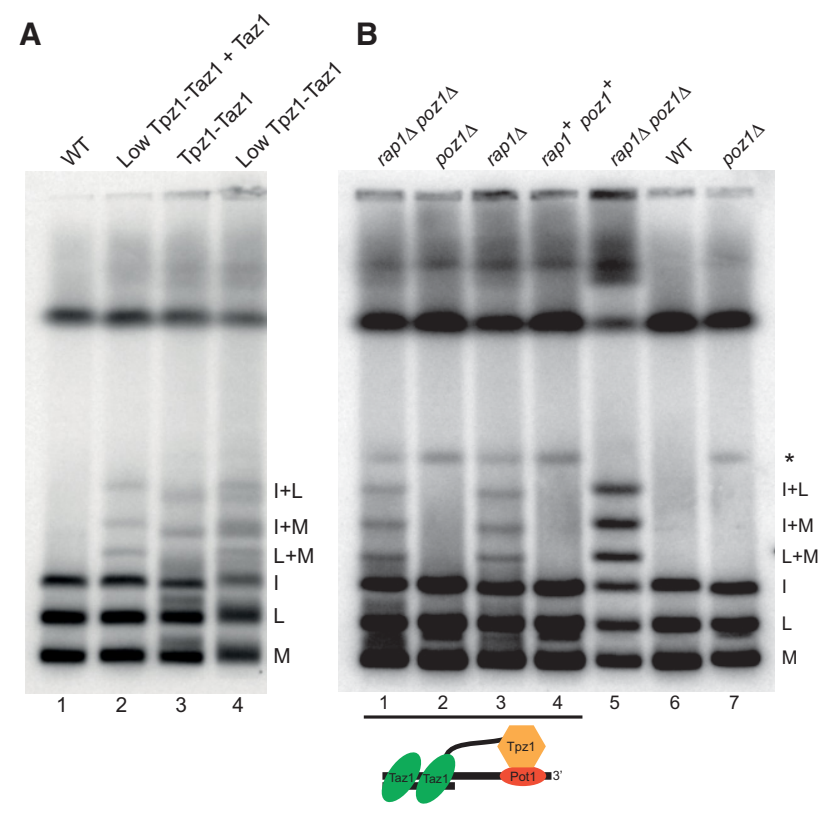

Figure 7. Chromosome end fusion analysis of minishelterin cells. (A) Minishelterin complexes do not protect cells against chromosome end fusions. (B) Rap1, but not Poz1, restores end protection. Nitrogen-starved cells were analyzed by pulsed-field gel electrophoresis (PFGE) with internal C, I, L, and M probes. In order to gain a better signal of the bands representing chromosome fusions, we crossed the cells with $972 \mathrm{~h}^{-}$wild-type cells to eliminate the auxotrophic markers (ade6-M210, leu1-32, ura4-D18, and his3-D1). The band marked with an asterisk arises from cross-hybridization of the I, L, M, and C probe mix with another NotI fragment in certain strain backgrounds. It is not a fusion product. 
length or by bridging Tazl and Pozl. Instead, the protein itself is required to prevent end fusions, possibly by directly recruiting a factor that inhibits NHEJ. Consistent with length regulation and protection from NHEJ being separable, deletion of poz1 did not result in end fusions in G1-arrested cells despite dramatically elongated telomeres (Fig. 7B, lane 7). To verify that Rap1, but not Poz1, is required for capping in G1, we examined cells containing the Tpz1-Rap1 fusion in the absence of endogenous Rap1, Poz1, and Tpz1. Whereas chromosome end fusions were readily detected in a rap $1 \Delta$ poz $1 \Delta$ control, they were not observed following the introduction of the Tpz1-Rap1 fusion (Supplemental Fig. S7).

\section{Discussion}

By systematically deleting domains and generating fusions among the core telomeric proteins, we defined minimal requirements for maintaining wild-type telomere length homeostasis. Minishelterin strains lacking Rap1 and Pozl support normal growth, maintain TPE, and guard against telomere entanglements in the cold. However, minishelterin is insufficient to protect against chromosome end fusions when cells are arrested in G1. To our knowledge, this is the first example of fission yeast cells with wild-type telomere length undergoing chromosome end fusions, thereby separating functions in end protection and length regulation. These observations led us to the identification of a direct role for Rapl in inhibiting end-joining at chromosome ends. Our study supports the model that a proteinaceous bridge between the doubleand single-stranded regions of each telomere is critical for maintaining telomere length by limiting access to telomerase. What is surprising, though, is how few constraints are placed on this higher-order structure. Neither the primary sequence nor the overall structure of Rap1 and Pozl make any discernable contribution to length regulation as long as Tazl and Tpzl are physically connected. Even the physical distance between Tazl and Tpzl is not critical, as the $80-\mathrm{kDa}$ Rapl and 30-kDa Pozl proteins can be replaced by a 14-amino-acid linker. In addition, opening the bridge does not require dynamic protein-protein interactions between Taz1-Rap1, Rap1-Poz1, or Poz1Tpz1, as covalent linkers at any of those positions do not impair telomere length homeostasis. Furthermore, in the minishelterin cells, the only protein-protein interaction that could be disrupted to produce an open conformation is the Tpzl-Pot1 interaction. Interestingly, replacing this interaction with a covalent linker results in shorter but stable telomeres, indicating that a dynamic nature of this interface may yet be important for regulating telomere elongation (Fig. 1D).

\section{Why telomere length regulation is sensitive to Taz1 levels}

A comparison of the level of fusion proteins containing Tpzl with the endogenous protein level revealed that the amount of Tpzl normally present in cells is far greater than the amount required for maintaining wild-type telo- mere length if a physical tether connects Tpzl with Tazl or Rap1, respectively. This could mean that Tpzl is inefficiently recruited to telomeres and that cells normally contain a large pool of non-telomere-associated Tpzl. Alternatively, there may be many telomeric complexes containing Taz1, Rap1, Poz1, Tpz1, and, by inference, Pot1 along the length of the telomere, but a much smaller fraction of these complexes is required for maintaining wildtype telomere length. Examination of the stoichiometry and abundance of human shelterin components revealed that there is sufficient TRF1 and TRF2 to cover all telomeric DNA and sufficient RAP1 and TIN2 to saturate all binding sites on TRF2 and TRF1/2, respectively (Takai et al. 2010). In contrast, there is $\sim 10$-fold less POT $1 /$ TPP1, indicating that telomere length maintenance in human cells requires only a subset of telomeric complexes to contain these shelterin subunits. Interestingly, a 10-fold reduction in the amount of TRF2 via shRNA treatment resulted in telomere elongation in HTC75 cells (Takai et al. 2010). We observed the same effect on telomere length homeostasis when the amount of Taz1 was reduced due to it being expressed as part of a chimeric protein under the control of the Pozl or Tpzl promoter. This effect was rescued by supplementation with an endogenous copy of Taz1, consistent with Tazl functioning as part of a counting mechanism as described for Rap1 in budding yeast (Marcand et al. 1997). A requirement for coating the bulk of telomeric DNA with Tazl to limit telomere elongation is also supported by the observation that the dramatic telomere elongation seen in rap $1 \Delta$ cells is partially rescued by overexpression of Taz1 (Dehe et al. 2012). Taken together, these results suggest that telomere length homeostasis requires sufficient Taz1 to coat the available repeats in addition to a physical link between the single-stranded overhang and internal telomeric sequences.

\section{Separation of functions at telomeres}

As telomeric protein complexes protect chromosome termini from DNA repair activities, they simultaneously limit access to telomerase. A key challenge in telomere maintenance is associated with permitting telomeraseregulated access while keeping ends protected from repair-associated ligation events. The identification of multiple protein-protein interactions among the core telomeric proteins has led to the view that they work as a functional unit. Although in vitro characterization of subcomplexes identified functions for TRF2/RAP1 in end protection (Bae and Baumann 2007) and for POT1/ TPP1 in telomerase recruitment and regulation (Wang et al. 2007; Nandakumar et al. 2012), it has remained unclear whether these functions involve the entire shelterin in vivo. Our study identified a simplified shelterin that provides insights into separation of functions in cells. The minishelterin complexes are sufficient for telomere length maintenance and subtelomeric silencing but not for end protection. Deletion of rap1 or poz1 was previously shown to cause loss of TPE, as does deletion of taz1. Our study reveals that this is not due to a requirement for Rapl or Pozl per se but is rather a downstream 
consequence of compromised telomere length regulation or insufficient Tazl.

Despite wild-type telomere length, minishelterin fails to prevent chromosome end fusions in G1-arrested cells. Instead, Rap1, but not Poz1, is required. Intriguingly, end protection does not require the interaction between Rap1 and Poz1, as the entire Poz1 protein is dispensable in this context. This implies that the bridge between single- and double-stranded telomeric DNA is insufficient for end protection even though it is fully functional in length regulation and TPE. Our results further demonstrate that the end fusions observed in G1-arrested cells lacking Taz1 or Rap1 are not an indirect consequence of the dramatically elongated telomeres in these mutants but are directly attributable to functions for Tazl and Rapl in end protection, independent of their roles in telomere length regulation.

\section{The role of Rap1 in end protection}

Rap1 is the most highly conserved telomeric protein among eukaryotes. Besides the C-terminal RCT domain, the BRCT, Myb, and Myb-like domains are all present in yeast and mammals. In Saccharomyces cerevisiae, Rap1 binds DNA directly and functions as a transcription factor in addition to its role in telomere length maintenance and end protection. A direct role for Rap1 in preventing NHEJmediated telomere fusions has been demonstrated (Pardo and Marcand 2005). This is mediated at least in part by the RCT domain recruiting Rif2 and Sir4 (Marcand et al. 2008). In Schizosaccharomyces pombe, deletion of rap1 also results in NHEJ-mediated chromosome fusions (Miller et al. 2005). The results presented here suggest that SpRapl functions directly in end protection, presumably by recruiting another factor that locally inhibits NHEJ. In mammalian cells, Rap1 appears to have lost its role in end protection. Knockout of RAP1 in mouse and human cells does not cause telomere fusions (Sfeir et al. 2010; Kabir et al. 2014). It thus appears that even in the absence of Rap1, the two-step mechanism by which TRF2 inhibits ATM activation and propagation of a DNA damage signal at telomeres is sufficient to protect against fusions (Okamoto et al. 2013). However, artificially tethering RAP1 to human telomeres rescues the end protection defect associated with the loss of TRF2 (Sarthy et al. 2009). This indicates that the protective function of RAP1 is still present in the mammalian orthologs but is now masked by redundant mechanisms that only require TRF2 to inhibit a DNA damage response at telomeres. Considering the importance of maintaining genome stability, it is not surprising that end protection is built on a multilayered system of redundant inhibition of double-strand break repair at chromosome ends. Further dissecting and individually characterizing each of the pathways that inhibit repair events at telomeres in different organisms will be important for understanding the relative contributions in each system. Defects in one pathway may well result in subtle increases in uncapping that are too weak to be picked up by conventional assays yet are significant in the context of genome instability and cancerogenesis.

\section{Materials and methods}

Strains and constructs

Strains used in this study are listed in Supplemental Table S1. Genomic integrations were generated by one-step gene replacement (Bahler et al. 1998). The tpz1-taz1 fusion construct was made by fusion PCR of V5 epitope-tagged taz1 followed by the natMX6 cassette and flanked by the last 750 base pairs (bp) of the tpz1 ORF and $\sim 750$ bp of the tpz1 $3^{\prime}$ untranslated region as upstream and downstream homology regions. This linear fragment was integrated at the endogenous tpz1 locus by lithium acetate transformation. Other fusion constructs were made using the same strategy. Primers used for fusion PCR are listed in Supplemental Table S2. The tpz1-taz1 overexpression strain was made by inserting the tpz1-V5-taz1-coding region into the pCST159 plasmid (Chikashige et al. 2006). The plasmid was then linearized with MscI and integrated at the aur1 locus in PP1029. Telomerase knockout strains were generated by crossing with $\operatorname{trt} 1:: \mathrm{ura}^{+}$ or $\operatorname{trt} 1:$ :his $3^{+}$strains followed by selection of correct genotypes and PCR verification. Similarly, strains lacking auxotrophic markers were generated by crossing with PP265.

\section{Denatured protein extract and Western blotting}

Western analysis was carried out following a previously published procedure (Bunch et al. 2005). Cells $\left(1 \times 10^{8}\right)$ were harvested and lysed by vortexing with 0.5 -mm glass beads in $10 \%$ trichloroacetic acid for $8 \mathrm{~min}$ at $4^{\circ} \mathrm{C}$. Beads were washed with $10 \%$ trichloroacetic acid, and the precipitate was collected by centrifugation at $16,000 \mathrm{~g}$ for $2 \mathrm{~min}$. Pellets were washed once with acetone and resuspended in $120 \mu \mathrm{L}$ of $1 \times$ protein sample buffer $(1 \times$ NuPAGE LDS buffer, $50 \mathrm{mM}$ dithiothreitol, $2 \%$ [w/v] sodium dodecyl sulfate). Samples were incubated for $5 \mathrm{~min}$ at $75^{\circ} \mathrm{C}$ and centrifuged at $16,000 \mathrm{~g}$ for $1 \mathrm{~min}$. The soluble fraction was loaded onto a $4 \%-$ $12 \%$ NuPAGE Bis-Tris gel (Life Technologies). Electrophoresis was carried out in $1 \times$ MOPS buffer (Life Technologies) at $200 \mathrm{~V}$ for $50 \mathrm{~min}$. Proteins were then transferred to Protran nitrocellulose membranes (Whatman) in Western transfer buffer $(3.03 \mathrm{~g} / \mathrm{L}$ Tris, $14.4 \mathrm{~g} / \mathrm{L}$ glycine, $20 \%$ [v/v] methanol) at $100 \mathrm{~V}$ for $1 \mathrm{~h}$. Blots were blocked in $1 \times$ TTBS $(20 \mathrm{mM}$ Tris- $\mathrm{HCl}$ at $\mathrm{pH} 7.5$, $137 \mathrm{mM}$ sodium chloride, $0.1 \%[\mathrm{v} / \mathrm{v}]$ Tween-20) with $5 \%(\mathrm{w} / \mathrm{v})$ nonfat milk and probed with mouse monoclonal anti-V5 antibody at a 1:5000 dilution (Life Technologies, 46-0705) and horseradish peroxidase-conjugated goat anti-mouse $\operatorname{IgG}(\mathrm{H}+\mathrm{L})$ at a 1:5000 dilution (Thermo Scientific, 31430). Bands were visualized with ECL 2 substrate (Pierce) on a Typhoon 8600 scanner (GE Healthcare Life Sciences) or Amersham Hyperfilm ECL (GE Healthcare Life Sciences). Blots were then stripped with stripping buffer (15 g/L glycine, 0.1\% [w/v] sodium dodecyl sulfate, $1 \%$ [v/ v] Tween-20 at $\mathrm{pH} 2.2$ ) and reprobed with mouse monoclonal anti-a-tubulin at a 1:20,000 dilution (Sigma-Aldrich, T5168) and horseradish peroxidase-conjugated goat anti-mouse $\operatorname{IgG}(\mathrm{H}+\mathrm{L})$ at a 1:5000 dilution (Thermo Scientific, 31430). For detection of phosphorylated Chk1, extracts were loaded onto a $50 \mu \mathrm{M}$ SuperSep Phos-tag 10\% gel. Electrophoresis was carried out in Tris-glycine running buffer (25 mM Tris, $192 \mathrm{mM}$ glycine, $0.1 \%$ SDS ) at $20 \mathrm{~mA}$ for $4 \mathrm{~h}$. The gel was soaked three times with gentle agitation for $10 \mathrm{~min}$ in Western transfer buffer containing $5 \mathrm{mM}$ EDTA and then once for $15 \mathrm{~min}$ in transfer buffer without EDTA. Proteins were transferred to PVDF membrane in Western transfer buffer at $150 \mathrm{~mA}$ overnight. The blot was blocked in $1 \times$ PBST $(8$ $\mathrm{g} / \mathrm{L}$ sodium chloride, $1.44 \mathrm{~g} / \mathrm{L}$ sodium phosphate dibasic, $0.2 \mathrm{~g} / \mathrm{L}$ potassium chloride, $0.24 \mathrm{~g} / \mathrm{L}$ potassium phosphate monobasic, $0.1 \%[\mathrm{v} / \mathrm{v}]$ Tween-20 at $\mathrm{pH} 7.2)$ with $5 \%(\mathrm{w} / \mathrm{v})$ nonfat milk and probed with mouse monoclonal anti-c-Myc clone 9E10 antibody 
at a 1:5000 dilution (Sigma-Aldrich, M4439) and horseradish peroxidase-conjugated goat anti-mouse $\operatorname{IgG}(\mathrm{H}+\mathrm{L})$ at a 1:5000 dilution (Thermo Scientific, 31430). Blots were then reprobed with mouse monoclonal anti-a-tubulin at a 1:20,000 dilution (SigmaAldrich, T5168) and horseradish peroxidase-conjugated goat anti-mouse $\operatorname{IgG}(\mathrm{H}+\mathrm{L})$ at a 1:5000 dilution (Thermo Scientific, 31430) as a loading control.

\section{Genomic DNA preparation and telomere length analysis}

Procedures were essentially as described in Bunch et al. (2005). Cells $\left(\sim 1 \times 10^{9}\right)$ were harvested and washed once with $\mathrm{ddH}_{2} \mathrm{O}$ and once with $\mathrm{Z}$ buffer $(50 \mathrm{mM}$ sodium citrate, $50 \mathrm{mM}$ sodium phosphate dibasic, $40 \mathrm{mM}$ EDTA at $\mathrm{pH} 7.8$ ) followed by incubation in $2 \mathrm{~mL}$ of Z buffer plus $0.5 \mathrm{mg} / \mathrm{mL}$ Zymolase T100 (US Biological) and $2 \mathrm{mM}$ dithiothreitol for $1 \mathrm{~h}$ at $37^{\circ} \mathrm{C}$. Sodium dodecyl sulfate was then added to a final concentration of $2 \%(\mathrm{w} / \mathrm{v})$, and incubation was continued for $10 \mathrm{~min}$ at $65^{\circ} \mathrm{C}$. The volume was then increased to $10 \mathrm{~mL}$ with $5 \times$ TE $(50 \mathrm{mM}$ Tris- $\mathrm{HCl}$ at $\mathrm{pH}$ 8.0, $5 \mathrm{mM}$ EDTA), and proteinase $\mathrm{K}$ (Sigma-Aldrich) was added to $50 \mu \mathrm{g} / \mathrm{mL}$. After $1 \mathrm{~h}$ of incubation at $50^{\circ} \mathrm{C}$, samples were precipitated with $3 \mathrm{~mL}$ of $5 \mathrm{M}$ potassium acetate for $30 \mathrm{~min}$ on ice, and the precipitate was removed by two rounds of centrifugation at $3200 \mathrm{~g}$ for $10 \mathrm{~min}$. The supernatant was then mixed with 1 vol of $100 \%$ isopropanol. After $20 \mathrm{~min}$ on ice, DNA was collected by centrifugation at $10,500 \mathrm{~g}$ for $10 \mathrm{~min}$ and resuspended in $5 \times$ TE with $50 \mu \mathrm{g} / \mathrm{mL}$ RNase A. After $1 \mathrm{~h}$ of incubation at $37^{\circ} \mathrm{C}$, DNA was extracted twice with phenol:chloroform:isoamyl alcohol (25:24:1, equilibrated with $5 \times \mathrm{TE})$ and once with chloroform: isoamyl alcohol (24:1, equilibrated with $5 \times \mathrm{TE})$ and then precipitated for $1 \mathrm{~h}$ at $-20^{\circ} \mathrm{C}$ following the addition of $2.5 \mathrm{vol}$ of ethanol. DNA was collected by centrifugation at $16,000 \mathrm{~g}$ for $10 \mathrm{~min}$ followed by one wash with $70 \%$ ethanol. DNA was solubilized in $1 \times$ TE buffer prior to quantification.

Genomic DNA was digested with EcoRI for $12 \mathrm{~h}$ and then loaded onto a $1 \%$ agarose gel and electrophoresed in $0.5 \times$ TBE $(44.5$ $\mathrm{mM}$ Tris-borate, $1 \mathrm{mM}$ EDTA at $\mathrm{pH}$ 8.3) at $120-160 \mathrm{~V}$ for 4-6 h. Gels were stained with $1 \mu \mathrm{g} / \mathrm{mL}$ ethidium bromide and visualized with a Typhoon 8600 scanner to confirm equal loading. Gels were then incubated in $0.25 \mathrm{M}$ hydrochloric acid for $10 \mathrm{~min}$ followed by $0.5 \mathrm{M}$ sodium hydroxide and $1.5 \mathrm{M}$ sodium chloride buffer for $30 \mathrm{~min}$ and $0.5 \mathrm{M}$ Tris- $\mathrm{HCl}(\mathrm{pH} 7.5)$ and $1.5 \mathrm{M}$ sodium chloride for $30 \mathrm{~min}$. DNA was transferred to Amersham Hybond$\mathrm{N}^{+}$membrane (GE Healthcare Life Sciences) via capillary blotting. DNA was cross-linked to the membrane in a Stratalinker using 254-nm UV light at $120 \mathrm{~mJ} / \mathrm{cm}^{2}$. A probe specific for telomeric sequences was generated by PCR from pTELO using T3 $\left(5^{\prime}\right.$-ATTAACCCTCACTAAAGGGA-3') and T7 (5'-TAATACGA CTCACTATAGGG-3') primers. A probe specific for the rad16 gene was generated by PCR from wild-type genomic DNA using primers XWP9 (5'-ATGGTATTTTTTCGCCATTTACTCG-3') and XWP10 (5'-TAGGCGGATCGTGAAGTTAA- $\left.{ }^{\prime}\right)$. Both probes were labeled by random hexamer labeling with $\left[\alpha^{32} \mathrm{P}\right]$ dCTP and High Prime (Roche). Hybridizations were carried out with 5 million cpm of probe in Church-Gilbert buffer (Church and Gilbert 1984) at $65^{\circ} \mathrm{C}$. Blots were exposed to PhosphorImager screens that were then analyzed with a Typhoon 8600 scanner.

\section{Native protein extract and coimmunoprecipitation}

Cultures ( $1.5 \mathrm{~L}$ ) were grown to a density of $0.5-1 \times 10^{7}$ cells per milliliter and harvested by centrifugation for the preparation of cell-free extract (Leonardi et al. 2008). Cells were washed three times with ice-cold TMG(300) buffer $(10 \mathrm{mM}$ Tris-HCl at $\mathrm{pH}$ 8.0, $1 \mathrm{mM}$ magnesium chloride, $10 \%$ [v/v] glycerol, $300 \mathrm{mM}$ sodium acetate). The cells were resuspended in two packed cell volumes of TMG(300) plus supplements $(1 \mu \mathrm{g} / \mathrm{mL}$ pepstatin A, $5 \mu \mathrm{g} / \mathrm{mL}$ leupeptin, $5 \mu \mathrm{g} / \mathrm{mL}$ chymostatin, $1 \mathrm{mM}$ benzamidine, $0.5 \mathrm{mM}$ PMSF, $1 \mathrm{mM}$ EDTA, $0.5 \mathrm{mM}$ dithiothreitol) and then frozen as beads in liquid nitrogen. Cells were lysed in a 6850 freezer mill (SPEX SamplePrep) using eight 2-min cycles at a rate of 10 per second with 2-min cooling intervals between cycles. Lysates were then thawed, and extracts were cleared by centrifugation at $5645 \mathrm{~g}$ for $10 \mathrm{~min}$ and two additional rounds of centrifugation at $16,000 \mathrm{~g}$ for $7 \mathrm{~min}$. The final supernatant was collected, and protein concentration was determined by Bradford assay.

Extracts $(6 \mathrm{mg})$ were diluted to $10 \mathrm{mg} / \mathrm{mL}$ with TMG(300) buffer plus supplements. Fifty microliters was mixed with $2 \times$ protein sample buffer as input. Extract $(550 \mu \mathrm{L})$ was mixed with $600 \mu \mathrm{L}$ of TMG(300) buffer plus supplements, and Tween-20 was added to $0.1 \%(\mathrm{v} / \mathrm{v})$. Five microliters of $25 \mathrm{U} / \mu \mathrm{L}$ Benzonase nuclease (EMD Biosciences) was added where indicated prior to the immunoprecipitations. Immunoprecipitations were performed with $40 \mu \mathrm{L}$ of Ezview Red anti-HA affinity gel (Sigma-Aldrich, E6779) for $4 \mathrm{~h}$ at $4^{\circ} \mathrm{C}$ with gentle rotation and then washed three times with TMG(200) [as TMG(300) except $200 \mathrm{mM}$ sodium acetate] plus supplements and $0.1 \%(\mathrm{v} / \mathrm{v})$ Tween-20 and once with TMG(50) [as TMG(300) but $50 \mathrm{mM}$ sodium acetate] plus supplements. The affinity gel was resuspended in $115 \mu \mathrm{L}$ of $1 \times$ LDS sample buffer, heated for $10 \mathrm{~min}$ at $75^{\circ} \mathrm{C}$, and centrifuged at $16,000 \mathrm{~g}$ for $1 \mathrm{~min}$. Ten microliters of the immunoprecipitation and input samples was used for Western blot analysis as described above except for using the following antibodies: Primary antibodies used were rabbit polyclonal anti-HA antibody at a 1:5000 dilution (Abcam, Ab9110) and rabbit polyclonal anti-V5 antibody at a 1:2000 dilution (Abcam, Ab9116); the secondary antibody was HRP-conjugated goat anti-rabbit IgG $(\mathrm{H}+\mathrm{L})$ antibody at a 1:5000 dilution (Thermo Scientific, 31460).

\section{Pulsed-field gel electrophoresis (PFGE)}

PFGE was carried out as in Baumann and Cech (2000). Cells were harvested and washed twice with SP1 buffer (1.2 M D-sorbitol, $50 \mathrm{mM}$ sodium citrate, $50 \mathrm{mM}$ sodium phosphate dibasic, $40 \mathrm{mM}$ EDTA at pH 5.6). Cells $\left(4 \times 10^{8}\right)$ were lysed with Zymolyase T-100 (final concentration of $0.375 \mathrm{mg} / \mathrm{mL}$ ) for $2 \mathrm{~h}$ at $37^{\circ} \mathrm{C}$. Cells were centrifuged at $845 \mathrm{~g}$ for 2 min, gently resuspended in $40 \mu \mathrm{L}$ of TSE buffer $(10 \mathrm{mM}$ Tris- $\mathrm{HCl}$ at $\mathrm{pH}$ 7.5, 0.9 M D-sorbitol, $45 \mathrm{mM}$ EDTA), and then mixed with $220 \mu \mathrm{L}$ of $1 \%$ low-melting-point agarose (Bio-Rad, 161-3112) in TSE buffer equilibrated at $50^{\circ} \mathrm{C}$. The cell suspension was then transferred into four plug molds (Bio-Rad, 170-3706). Solidified plugs were washed in PW1 buffer (50 mM Tris- $\mathrm{HCl}$ at pH 7.5, 0.25 M EDTA, $1 \%$ [w/v] sodium dodecyl sulfate) for $2 \mathrm{~h}$ at $50^{\circ} \mathrm{C}$ followed by two rounds of $24 \mathrm{~h}$ of treatment with $1 \mathrm{mg} / \mathrm{mL}$ proteinase $\mathrm{K}$ in PW2 buffer (10 mM Tris- $\mathrm{HCl}$ at $\mathrm{pH} 9.0,0.5 \mathrm{M}$ EDTA, 1\% [w/v] N-lauroyl sarcosine) at $50^{\circ} \mathrm{C}$. After three 15 -min washes with T10xE (10 $\mathrm{mM}$ Tris- $\mathrm{HCl}$ at $\mathrm{pH} 7.5,10 \mathrm{mM}$ EDTA), plugs were stored at $4^{\circ} \mathrm{C}$ until use.

For NotI digestions, plugs were washed twice for $15 \mathrm{~min}$ in $1 \times$ TE at $50^{\circ} \mathrm{C}$ and then incubated for $2-5 \mathrm{~h}$ with $1 \times$ NEBuffer 3.1 (New England Biolabs). Plugs were then incubated for $3 \mathrm{~h}$ at $37^{\circ} \mathrm{C}$ with $500 \mu \mathrm{L}$ of fresh $1 \times$ NEBuffer 3.1 buffer containing 100 $\mathrm{U}$ of NotI (New England Biolabs). An additional $100 \mathrm{U}$ of NotI was then added, and plugs were again incubated for $3 \mathrm{~h}$. After washing in T10xE and equilibrating in $0.5 \times \mathrm{TBE}$ for $30 \mathrm{~min}$, plugs were loaded onto $1 \%$ agarose gels (pulsed-field certified agarose; Bio-Rad, 162-0137). Electrophoresis was carried out in recirculating $0.5 \times \mathrm{TBE}$ buffer at $6 \mathrm{~V} / \mathrm{cm}$ for $24 \mathrm{~h}$ at $14^{\circ} \mathrm{C}$ with a 60 - to 120 -sec switch ramp at an included angle of $120^{\circ}$. Southern transfer and hybridization was carried out using the same protocol described above with the following modifications. Instead of hydrochloric 
acid treatment, gels were first irradiated with $120 \mathrm{~mJ} / \mathrm{cm}^{2}$ of UV to nick the DNA before sodium hydroxide treatment. Probes specific for the end fragments (L, I, M, and C) were generated by PCR from wild-type genomic DNA and labeled by random hexamer labeling with $\left[a^{-32} \mathrm{P}\right]$-dCTP and High Prime (Roche). Primers used to amplify these fragments were LT $\left(5^{\prime}\right.$-TTTGTTGACTGGTA CAATCAATGCTGGCTG- $\left.3^{\prime}\right)$ and LB (5'-AAGAAGCATAT CGATTGGAAAGCAGCTCCA-3'), IT (5'-ATGTGCGGAATT TTGGCGTTAATGCTTGCT- $\left.3^{\prime}\right)$ and IB (5'-ACACATGCATAA CCACCATTAACGCGATCG-3' $\left.{ }^{\prime}\right)$, MT (5'-GATCGCGTGTCC ATCGTCCATTAGCTTCTT-3') and MB (5'-GGTAGTGCTAG ATGGACTGCGGAACATTGG-3 $\left.{ }^{\prime}\right)$, and CT $\left(5^{\prime}\right.$-ATGAGAGA AGTAATTTCTGTTCATGTTGGA-3') and CB (5' -CTCAATGT CAAGATTTCGGCGACAGATATC-3').

\section{Acknowledgments}

We thank Julia Cooper and Toru Nakamura for generously sharing strains and communicating data prior to publication, Chen $\mathrm{Li}$ and Evan Janzen for technical assistance, and other members of the Baumann laboratory for discussions. This work was funded in part by the Stowers Institute for Medical Research. P.B. is an Investigator with the Howard Hughes Medical Institute. L.P. and P.B. designed the experiments; L.P. performed most of the experiments; K.H. contributed to the generation of strains and genomic DNA preparation and performed the spotting assay for TPE characterization; C.S. and N.T. mapped the PI domain, shared unpublished data, and provided valuable input on the generation of fusion constructs; and L.P. and P.B. analyzed that data and wrote the manuscript.

\section{References}

Bae NS, Baumann P. 2007. A RAP1/TRF2 complex inhibits nonhomologous end-joining at human telomeric DNA ends. Mol Cell 26: 323-334.

Bahler J, Wu JQ, Longtine MS, Shah NG, McKenzie A III, Steever AB, Wach A, Philippsen P, Pringle JR. 1998. Heterologous modules for efficient and versatile PCR-based gene targeting in Schizosaccharomyces pombe. Yeast 14: 943-951.

Baumann P, Cech TR. 2000. Protection of telomeres by the Ku protein in fission yeast. Mol Biol Cell 11: 3265-3275.

Baumann P, Cech TR. 2001. Pot1, the putative telomere endbinding protein in fission yeast and humans. Science 292: 1171-1175.

Broccoli D, Smogorzewska A, Chong L, de Lange T. 1997. Human telomeres contain two distinct Myb-related proteins, TRF1 and TRF2. Nat Genet 17: 231-235.

Bunch JT, Bae NS, Leonardi J, Baumann P. 2005. Distinct requirements for Pot1 in limiting telomere length and maintaining chromosome stability. Mol Cell Biol 25: 5567-5578.

Chen Y, Rai R, Zhou ZR, Kanoh J, Ribeyre C, Yang Y, Zheng H, Damay P, Wang F, Tsujii H, et al. 2011. A conserved motif within RAP1 has diversified roles in telomere protection and regulation in different organisms. Nat Struct Mol Biol 18: 213-221.

Chikashige Y, Hiraoka Y. 2001. Telomere binding of the Rap1 protein is required for meiosis in fission yeast. Curr Biol 11: $1618-1623$.

Chikashige Y, Tsutsumi C, Yamane M, Okamasa K, Haraguchi T, Hiraoka Y. 2006. Meiotic proteins bqt1 and bqt2 tether telomeres to form the bouquet arrangement of chromosomes. Cell 125: 59-69.

Church GM, Gilbert W. 1984. Genomic sequencing. Proc Nat1 Acad Sci 81: 1991-1995.
Cooper JP, Nimmo ER, Allshire RC, Cech TR. 1997. Regulation of telomere length and function by a Myb-domain protein in fission yeast. Nature 385: 744-747.

Dehe PM, Rog O, Ferreira MG, Greenwood J, Cooper JP. 2012. Tazl enforces cell-cycle regulation of telomere synthesis. Mol Cell 46: 797-808.

Fairall L, Chapman L, Moss H, de Lange T, Rhodes D. 2001. Structure of the TRFH dimerization domain of the human telomeric proteins TRF1 and TRF2. Mol Cell 8: 351-361.

Ferreira MG, Cooper JP. 2001. The fission yeast Tazl protein protects chromosomes from Ku-dependent end-to-end fusions. Mol Cell 7: 55-63.

Fujita I, Tanaka M, Kanoh J. 2012. Identification of the functional domains of the telomere protein Rap1 in Schizosaccharomyces pombe. PLoS One 7: e49151.

Harland JL, Chang YT, Moser BA, Nakamura TM. 2014. Tpz1Ccq1 and Tpzl-Pozl interactions within fission yeast shelterin modulate Ccq1 Thr93 phosphorylation and telomerase recruitment. PLoS Genet 10: e1004708.

Houghtaling BR, Cuttonaro L, Chang W, Smith S. 2004. A dynamic molecular link between the telomere length regulator TRF1 and the chromosome end protector TRF2. Curr Biol 14: 1621-1631.

Jun H, Liu J, Jeong H, Kim J, Qiao F. 2013. Tpzl controls a telomerase-nonextendible telomeric state and coordinates switching to an extendible state via Ccq1. Genes Dev 27: 1917-1931.

Kabir S, Hockemeyer D, de Lange T. 2014. TALEN gene knockouts reveal no requirement for the conserved human shelterin protein Rap1 in telomere protection and length regulation. Cell Rep 9: 1273-1280.

Kanoh J, Ishikawa F. 2001. spRap1 and spRif1, recruited to telomeres by Taz1, are essential for telomere function in fission yeast. Curr Biol 11: 1624-1630.

Leonardi J, Box JA, Bunch JT, Baumann P. 2008. TER1, the RNA subunit of fission yeast telomerase. Nat Struct Mol Biol 15: 26-33.

Liu D, Safari A, O'Connor MS, Chan DW, Laegeler A, Qin J, Songyang Z. 2004. PTOP interacts with POT1 and regulates its localization to telomeres. Nat Cell Biol 6: 673-680.

Marcand S, Gilson E, Shore D. 1997. A protein-counting mechanism for telomere length regulation in yeast. Science 275: 986-990.

Marcand S, Brevet V, Gilson E. 1999. Progressive cis-inhibition of telomerase upon telomere elongation. EMBO I 18: 35093519.

Marcand S, Pardo B, Gratias A, Cahun S, Callebaut I. 2008. Multiple pathways inhibit NHEJ at telomeres. Genes Dev 22: 1153-1158.

Miller KM, Cooper JP. 2003. The telomere protein Taz1 is required to prevent and repair genomic DNA breaks. Mol Cell 11: 303-313.

Miller KM, Ferreira MG, Cooper JP. 2005. Taz1, Rap1 and Rif1 act both interdependently and independently to maintain telomeres. EMBO I 24: 3128-3135.

Miyoshi T, Kanoh J, Saito M, Ishikawa F. 2008. Fission yeast Pot1-Tpp 1 protects telomeres and regulates telomere length. Science 320: 1341-1344.

Nandakumar J, Bell CF, Weidenfeld I, Zaug AJ, Leinwand LA, Cech TR. 2012. The TEL patch of telomere protein TPP1 mediates telomerase recruitment and processivity. Nature 492: 285-289.

Nimmo ER, Pidoux AL, Perry PE, Allshire RC. 1998. Defective meiosis in telomere-silencing mutants of Schizosaccharomyces pombe. Nature 392: 825-828. 
Pan et al.

Okamoto K, Bartocci C, Ouzounov I, Diedrich JK, Yates JR III, Denchi EL. 2013. A two-step mechanism for TRF2-mediated chromosome-end protection. Nature 494: 502-505.

Pardo B, Marcand S. 2005. Rap1 prevents telomere fusions by nonhomologous end joining. EMBO / 24: 3117-3127.

Pfeiffer V, Lingner J. 2013. Replication of telomeres and the regulation of telomerase. Cold Spring Harb Perspect Biol 5: a010405.

Sarthy J, Bae NS, Scrafford J, Baumann P. 2009. Human RAP1 inhibits non-homologous end joining at telomeres. EMBO I 28: 3390-3399.

Sfeir A, Kabir S, van Overbeek M, Celli GB, de Lange T. 2010. Loss of Rap1 induces telomere recombination in the absence of NHEJ or a DNA damage signal. Science 327: $1657-1661$.
Spink KG, Evans RJ, Chambers A. 2000. Sequence-specific binding of Tazlp dimers to fission yeast telomeric DNA. Nucleic Acids Res 28: 527-533.

Takai KK, Hooper S, Blackwood S, Gandhi R, de Lange T. 2010. In vivo stoichiometry of shelterin components. J Biol Chem 285: 1457-1467.

Teixeira MT, Arneric M, Sperisen P, Lingner J. 2004. Telomere length homeostasis is achieved via a switch between telomerase-extendible and -nonextendible states. Cell 117: 323-335.

Wang F, Podell ER, Zaug AJ, Yang Y, Baciu P, Cech TR, Lei M. 2007. The POT1-TPP1 telomere complex is a telomerase processivity factor. Nature 445: 506-510.

Ye JZ, Hockemeyer D, Krutchinsky AN, Loayza D, Hooper SM, Chait BT, de Lange T. 2004. POT1-interacting protein PIP1: a telomere length regulator that recruits POT1 to the TIN2/ TRF1 complex. Genes Dev 18: 1649-1654. 


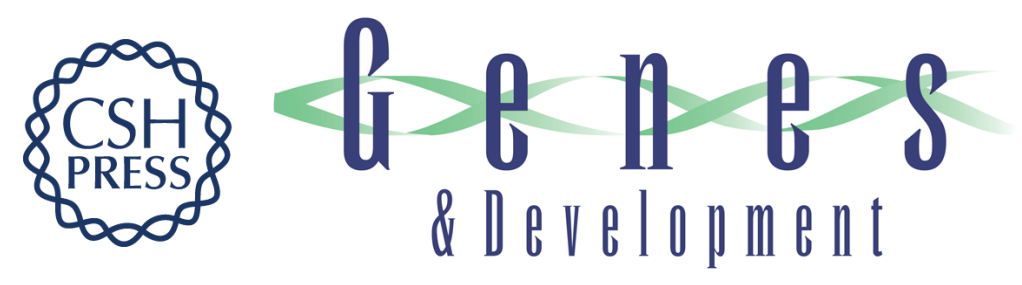

\section{Minishelterins separate telomere length regulation and end protection in fission yeast}

Lili Pan, Katie Hildebrand, Cian Stutz, et al.

Genes Dev. 2015, 29:

Access the most recent version at doi:10.1101/gad.261123.115

\section{Supplemental http://genesdev.cshlp.org/content/suppl/2015/06/10/29.11.1164.DC1 Material}

References This article cites 40 articles, 16 of which can be accessed free at: http://genesdev.cshlp.org/content/29/11/1164.full.html\#ref-list-1

Creative This article is distributed exclusively by Cold Spring Harbor Laboratory Press for the first Commons six months after the full-issue publication date (see

License http://genesdev.cshlp.org/site/misc/terms.xhtml). After six months, it is available under a Creative Commons License (Attribution-NonCommercial 4.0 International), as described at http://creativecommons.org/licenses/by-nc/4.0/.

Email Alerting Receive free email alerts when new articles cite this article - sign up in the box at the top Service right corner of the article or click here.

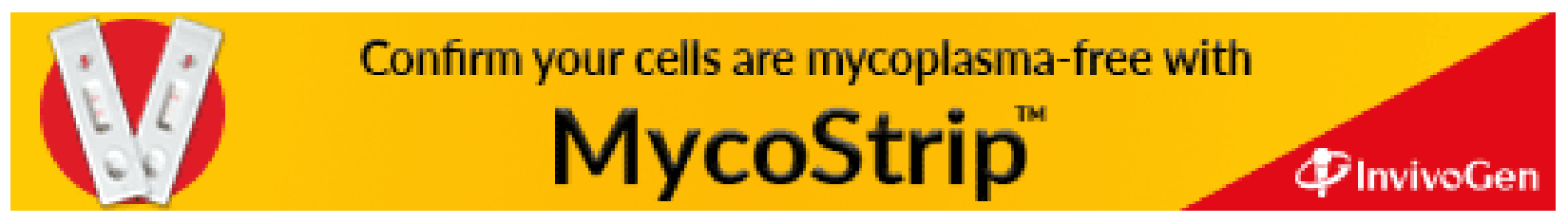

